\title{
Elaboration of pâté using fish residues
}

\author{
Elaboração de patê utilizando resíduos de pescado

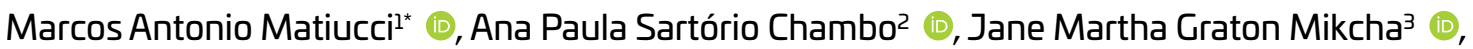 \\ Suzana Maria da Silva Réia ${ }^{4}$ (D), Kelly Cristina Vitorino ${ }^{4}$ (), Lorena Batista de Moura ${ }^{5}$ (D), \\ Andresa Carla Feihrmann ${ }^{1,6}$ (D), Maria Luiza Rodrigues de Souza2,4
}

\begin{abstract}
Knowing the potential of fish waste for the preparation of pâtés, there is the possibility of adding greater sustainability to the aquaculture sector. The aim was to prepare pâtés from fish processing residues with the inclusion of smoked fishmeal and evaluate their sensory, microbiological, physicochemical, and shelf-life characteristics. Three treatments were used: pâté without fishmeal inclusion (PSF), with smoked salmon carcass meal inclusion (PFSD), and smoked tilapia carcass meal (PFTD). The inclusion of the flours reduced the moisture, carbohydrate, and water activity. However, they increased the ash, salt, and collagen content. The lipid content was higher for the PFSD. The PSF showed peak oxidation at 15 days and the PFSD and PFTD around 45 days over the course of the 90-day shelf-life. The luminosity and $b^{*}$ coordinate were lower for PFTD, while the $\mathrm{a}^{*}$ coordinate was higher for PFSD. Only the $\mathrm{b}^{*}$ coordinate showed changes in PSF and PFSD throughout the 30 days of shelf-life, and its color tended to yellow at 15 days. The sensory analysis did not differ statistically between treatments $(p>0.05)$ for all attributes, except color, where the highest score was attributed to PSF. As for the overall impression, PSF also obtained the highest score, which may be associated with its color. By including fish flours, the nutritional composition and color of the tilapia-trimmed pâtés are changed, achieving an average acceptance level of $67 \%$.
\end{abstract}

KEYWORDS: Trimmings; Carcass; Oreochromis niloticus; Salmo salar.

\begin{abstract}
RESUMO: Sabendo-se do potencial dos resíduos de pescado para elaboraçáo de patês, tem-se a possibilidade de agregar maior sustentabilidade ao setor aquícola. Objetivou-se elaborar patês a partir de resíduos do beneficiamento de pescado com a inclusão de farinhas de peixe defumadas e avaliar as características sensoriais, microbiológicas, física-químicas e shelf-life. Utilizou-se três tratamentos: patê sem inclusão de farinhas de peixe (PSF), com inclusão de farinhas de carcaças de salmão defumadas, (PFSD) e farinha de carcaça de tilápia defumadas (PFTD). As inclusões das farinhas reduziram a umidade, carboidratos e atividade de água. Entretanto elevaram os teores de cinzas, sal e colágeno. O teor de lipídeos foi maior para o PFSD. O PSF apresentou pico de oxidaçáo aos 15 dias e o PFSD e PFTD por volta dos 45 dias no decorrer dos 90 dias de shelf-life. A luminosidade e coordenada $b^{*}$ foram menores para PFTD, enquanto a coordenada $a^{*}$ maior para PFSD. Apenas a coordenada $b^{*}$ apresentou alteração no PSF e PFSD ao longo dos 30 dias de shelf-life, cuja cor tendeu ao amarelo aos 15 dias. A análise sensorial não diferiu estatisticamente entre os tratamentos $(\mathrm{p}>0,05)$ para todos os atributos, exceto cor, onde maior nota foi para PSF. Quanto a impressão global o PSF também obteve a maior nota, o que pode estar associado à sua coloração. Ao incluir farinhas de peixe altera a composição nutricional e a cor dos patês de aparas de tilápia, obtendo um nível médio de aceitação de $67 \%$.
\end{abstract}

PALAVRAS-CHAVE: Aparas; Carcaça; Oreochromis niloticus; Salmo salar.

\section{INTRODUCTION}

The growing and significant demand for products from Brazilian aquaculture coupled with the changing consumer profile has raised interest in relation to processed fish foods, because there is a growing search for practical and nutritious foods (MATIUCCI et al., 2019). This increase in fish production has generated a problem, which is the large amount of waste that ends up being discarded in the environment (MINOZZO; WASZCZYNKYJ; BOSCOLO, 2008).

The use of these residues in a cautious and technological way is still inexpressive, and the biomass formed by these

'Post Graduate in Food Science, Agricultural Sciences Center, State University of Maringá, Maringá, PR, Brazil

2Post Graduate in Animal Science, Agricultural Sciences Center, State University of Maringá, Maringá, PR, Brazil ${ }^{3}$ Health Sciences Center, State University of Maringá, PR, Brazil

${ }^{4}$ Department of Animal Science, Agricultural Sciences Center, State University of Maringá, Maringá, PR, Brazil

${ }^{5}$ Federal Rural University of Amazonia, Capitão Poço, PA, Brazil

${ }^{6}$ Department of Food Engineering, Technology Center, State University of Maringá, Maringá, PR, Brazil

*Corresponding author: m.matiucci@hotmail.com

Received: 08/06/2020. Accepted: 06/10/2020 
residues, head, fins, skin, viscera, and spine can represent more than $50 \%$ of the fish (SILVA et al., 2009). Thus, it is necessary to develop technologies to take full advantage of fish, promoting sustainability and economic return for the sector. From another perspective, the growing interest in this product is also important, mainly due to the nutritional quality of these residues, such as omega 3, calcium, phosphorus, iron, and amino acids (Souza et al., 2017).

For example, the process of filleting tilapia generates large amounts of waste, which are used in flour or silage production, or discarded into the environment. Considering that the filleting process generates around $60 \%$ to $72 \%$ of residue, (KUBITZA, 2006), the search for more rational and viable ways to apply this residue is essential for the sector's sustainability.

The use of mechanically separated meat (MSM) and trimmings are a way to apply this waste in human food, serving as raw material for the production of sausages and restructured products, such as pâté, giving rise to products with higher added value. Studies using MSM from Pacu (Piaractus mesopotamicus), Jundiá (Rhandia quelen), and Tilapia (Oreochromis niloticus) to make pâtés have proven to be viable. The elaboration of products, such as pâtés and croquettes, diversifies the production line and generates co-products from the filleting industry, besides encouraging the increase of fish consumption from new processed products of greater convenience in preparation (BORDIGNON, et al., 2010; FEIDEN et al., 2010; MATIUCCI et al., 2019).

Another alternative is the elaboration of meal or protein concentrate from trimmings (commonly called the "V" cut of the filet), carcass and CMS, so that they can be included in food products consumed daily, as an alternative food that is economical and of social application, besides being highly nutritious (SOUZA et al., 2017).

The objective of this study was to elaborate pâtés using residues from the tilapia processing (fillet "V" cut) with and without the inclusion of smoked tilapia and salmon carcass flours and to evaluate the sensorial, microbiological, physicalchemical, and shelf-life characteristics.

\section{MATERIAL AND METHODS}

\section{Preparation of smoked flours from Nile tilapia and salmon carcasses}

The production of fishmeal was carried out at Fish Technology Laboratory of the Experimental Farm of Iguatemi (FEI), belonging to State University of Maringá- UEM. Carcasses of Nile tilapia (Oreochromis niloticus) from company Smart Fish (Rolândia, PR), and Salmon (Salmo salar) from company Tomita \& Tomita Ltda (Maringá, PR), were used.

The carcasses obtained in the filleting process were frozen and transported in an isothermal box up to Fish Technology Laboratory of the Experimental Farm of Iguatemi (FEI), at
State University of Maringá - UEM. At this location, when the flours were being prepared, the tilapia and salmon carcasses (bone without the fillets) were thawed at room temperature and the fins and heads were removed. The different raw materials were washed, weighed, and subjected to a brine in a 1:1 ratio of meat waste and water, containing $10 \%$ rock salt, $1 \%$ unnatural rosemary (Salvia rosmarinus), $0.1 \mathrm{mg} \cdot \mathrm{kg}^{-1}$ of Proxitane ${ }^{\circledR} 1512$ AL (sanitizer based on peracetic acid, hydrogen peroxide, acetic acid, and water) and $0.5 \mathrm{mg} \cdot \mathrm{kg}^{-1}$ of antioxidant butylated hydroxytoluene, BHT (BHT ACS 99.8\%, Labsynth Brazil) for 15 min. Afterwards they were dehydrated in a forced air circulation oven at $50{ }^{\circ} \mathrm{C}$ for 90 $\mathrm{min}$. Then they were taken for hot smoking for $150 \mathrm{~min}$. at $60^{\circ} \mathrm{C} \pm 90^{\circ} \mathrm{C}$ in a homemade stainless-steel smoker (dimensions: $\mathrm{H} 1.45 \mathrm{~m} \mathrm{x} \mathrm{W} 0.55 \mathrm{~m} \mathrm{x} \mathrm{D} 0.45 \mathrm{~m}$ ) with smoke generator, from the combustion of pink eucalyptus sawdust (Eucalyptus globulus), positioned outside the smoking chamber, and the temperature was maintained with the use of cooking gas.

After being smoked, the salmon and tilapia carcasses were pressed separately in a hydraulic press with a capacity of 10 tons to extract the excess water. The press cake was ground in a meat grinder and dehydrated in an oven with forced air circulation for drying at $55^{\circ} \mathrm{C}$ for 24 hours. The dehydrated material was submitted to a new grinding in a knife mill to obtain the salmon and tilapia flours, which were evaluated as to the characterization of their nutritional composition and used in the preparation of pâtés.

\section{Preparation of pâtés}

To prepare the pâtés, the frozen tilapia fillet trimmings were ground five times to reduce the size of the bones present. They were then weighed according to the treatments. The pâté formulations are shown in Table 1, differentiated by the inclusion or not of fish meal, resulting in three pâté formulations: Treatment 1 - pâté without fish meal (PSF), Treatment 2 - pâté with smoked salmon carcass meal (PFSD), and Treatment 3 pâté with smoked tilapia carcass meal (PFTD).

The ingredients were included according to the mentioned treatments (Table 1), with trimmings in natura $(40 \%)$ and pre-cooked ( $60 \%$ of the total trimmings plus the MSM) the homogenization occurred in a multiprocessor until a homogeneous mass was obtained. The finished dough was filled into polypropylene containers, identified, pasteurized in an oven, and stored under refrigeration $\left(+/-7^{\circ} \mathrm{C}\right)$ for 90 days to perform the shelf-life study. Initial samples were collected for microbiological, physicochemical, and sensory analysis.

\section{Evaluation of the shelf-life of pâtés}

The shelf-life study of the pâtés was conducted over 90 days. During this period, the pâtés were stored under refrigeration $\left(+/-7^{\circ} \mathrm{C}\right)$. Samples were collected at $0,15,30,45,60,75$, and 
90 days after storage for chemical analyses of lipid oxidation using thiobarbituric acid reactive substances (TBARs) and 0 , 15 , and 30 days for instrumental color analysis.

\section{Microbiological analysis of flours and pâtés}

The microbiological analyses of the flours and pâtés took place in the Laboratory of Microbiology and Food Microscopy of the Department of Clinical Analysis - State University of Maringá - UEM. They were performed to quantify the positive Staphylococcus coagulase expressed in colony forming units (CFU)/gram, the most probable number (MPN) of coliforms at 35 and $45^{\circ} \mathrm{C}$, and also the presence or absence of Salmonella spp, according to APHA (1992). The microbiological protocols followed the standards recommended by Resolution RDC No. 12 of January 2, 2001, of the National Health Surveillance Agency (BRASIL, 2001).

\section{Physical-chemical analysis}

\section{Centesimal composition and caloric value of flours and pâtés}

Analyses of the composition of the flours and pâtés were performed. For the characterization of the moisture and ash contents,

Table 1. Formulation of pâtés with inclusion of smoked flours from Nile tilapia and salmon carcasses

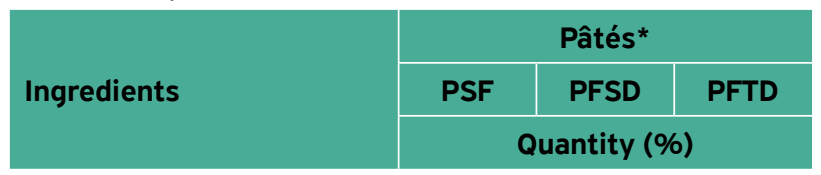

Formulation Basis

\begin{tabular}{l|c|c|c}
\hline Trimmings & 90 & 80 & 80 \\
\hline MSM & 10 & 10 & 10 \\
\hline Smoked Tilapia Flour & 0 & 0 & 10 \\
\hline Smoked Salmon Flour & 0 & 10 & 0 \\
\hline
\end{tabular}

Intended added

\begin{tabular}{l|c|c|c}
\hline Hydrogenated fat & 15.4 & 15.4 & 15.4 \\
\hline Ice & 11.5 & 11.5 & 11.5 \\
\hline Oatmeal & 2.3 & 2.3 & 2.3 \\
\hline Isolated soy protein & 1.4 & 1.4 & 1.4 \\
\hline Salt & 0.8 & 0.8 & 0.8 \\
\hline Monosodium glutamate & 1.5 & 1.5 & 1.5 \\
\hline Healing salts & 1.4 & 1.4 & 1.4 \\
\hline Sugar & 0.3 & 0.3 & 0.3 \\
\hline Onion cream & 3.1 & 3.1 & 3.1 \\
\hline Lemon Juice & 2.6 & 2.6 & 2.6 \\
\hline Seasonings* & 0.7 & 0.7 & 0.7 \\
\hline
\end{tabular}

** dehydrated garlic, dehydrated onion flakes, dehydrated green smell, nutmeg and black pepper. *PSF - pâté without fishmeal inclusion; PFSD - pâté with smoked salmon carcass meal inclusion; PFTD - pâté with smoked tilapia carcass meal inclusion. the method described according to the Association of Official Analytical Chemists was used (AOAC, 1997). For determination of the crude protein contents, the semi-micro Kjeldahl method was followed (SILVA; QUEIROZ, 2002). The carbohydrate contents were estimated using a mathematical formula that considers the carbohydrate content, the complementary value that must total $100 \%$, adding the contents of moisture, crude protein, lipids, and ash (BRASIL, 2003).

The lipids were extracted according to an adaptation of the method described by Bligh and Dyer (1959) using a solution of chloroform, methanol, and water in a proportion of 2:2:1.8 (v/v/v), respectively. The collagen was quantified by the methodology described by IAL (1985), through the quantification of the amino acid hydroxyproline.

The total caloric value was obtained by multiplying the means for protein and carbohydrates by factor 4 plus the multiplication of the lipid content by factor 9 (SOUCI et al., 2000).

\section{Colorimetry of pâtés}

The color of the samples was evaluated using Konica Minolta's CR-400 portable colorimeter (settings: Illuminant D65; $0^{\circ}$ viewing angle; and 4 self-average). Three readings were taken per sample at room temperature, and the results were expressed by the parameters $L^{*}$ (representing the percentage of brightness, where black means $0 \%$, and white, $100 \%$ ), a* (red-green component), and $\mathrm{b}^{*}$ (yellow-blue component), according to the CIELAB color system (DO AMARAL et al., 2012).

\section{Hydrogen potencial $(\mathrm{pH})$ and water activity $(\mathrm{Aw})$ of the pâtés}

The $\mathrm{pH}$ of the samples was measured using a homogenized solution of $10 \mathrm{~g}$ of sample diluted in $100 \mathrm{~mL}$ of distilled water. The solution was submitted to the electrodes of the $\mathrm{pH}$ meter (DM 22, Digimed, São Paulo, Brazil) for five minutes, and the $\mathrm{pH}$ reading was performed (IAL, 1985).

The water activity (Aw) was determined using an Aw Sprint - Novasina TH-500 device.

\section{Determination of lipid oxidation by thiobarbituric acid (TBARs) of pâtés}

To evaluate the lipid oxidation of the pâtés, the oxidation equivalent in malonaldehyde was observed through the TBARs methodology (JUNCHER et al., 2001). For the extraction of aldehydes, $5 \mathrm{~g}$ of the homogenized pâté sample was mixed with $15 \mathrm{~mL}$ of the extraction solution, and then homogenized in the Ultra Turax for 1 minute. Then the samples were filtered, and the filtrate was used for TBARs analysis. For the determination of TBARs-reactive substances, a $1.5 \mathrm{~mL}$ aliquot of the extract was transferred to $15 \mathrm{~mL}$ Falcon tubes, and $1.5 \mathrm{~mL}$ of the Thiobarbituric acid solution was added. 
It was then placed in a boiling bath $\left(100{ }^{\circ} \mathrm{C}\right)$ for $15 \mathrm{~min}$, cooled in ice water for $5 \mathrm{~min}$, and then the contents were added into the cuvettes. After reading at $532 \mathrm{~nm}$, distilled water was used as a blank.

\section{Sensory analysis of the pâtés}

The sensory analysis of the pâtés was performed with 50 untrained tasters, randomly numbering the samples in a room without an individual booth. For the sensory analysis, $40 \mathrm{~g}$ of each sample were provided with a toast. A glass with water was provided for cleaning the papillae, in addition to a sheet for sensory analysis. The attributes of aroma, color, flavor, texture, and overall acceptance were evaluated using a hedonic scale of nine points, with the extremes: 1 and 9, "I dislike very much" or "I like very much", respectively (MORAES, 1993; STONE; SIDEL, 1993; DUTCOSKY, 2011). The purchase intention was also evaluated using a 5-point hedonic scale, where the extremes 5 and 1 represent "would certainly buy" and "would definitely not buy", respectively, according to the methodology described for sensory analysis (MEILGAARD; CIVILE; CARR, 1991; DAMÁSIO; SILVA, 1996). The acceptance index was calculated using the formula IA $(\%)=(\mathrm{A} / \mathrm{B})$ $x 100$, where $A=$ presents the average score obtained by the product analyzed on the hedonic scale; $\mathrm{B}=$ represents the maximum grade that the product received on the hedonic scale (DUTCOSKY, 2011). The sensory analysis was evaluated and approved by the Ethics Committee of COPEP, with CAEE Registration: 71048517.2.0000.0104. The study was conducted according to the precepts of Resolution 196/96 of the National Health Council.

\section{Statistical Analysis}

An entirely randomized design with three treatments was used: pâté without flour (Trat 1, PSF), pâté with smoked salmon flour (Trat 2, PFSD), and pâté with smoked tilapia flour (Trat 3, PFTD), with five repetitions for each treatment.

\section{Statistical Delineation}

The design was entirely randomized with three treatments $($ Trat $1=$ PSF, Trat $2=$ PFSD, and Trat $3=$ PFTD $)$, with 5 repetitions. The results of the analyzed variables, composition, caloric value, $\mathrm{pH}$, and $\mathrm{Aw}$ were submitted to variance analysis, and the means were compared by Tukey's test at $5 \%$ probability level (SAS, 2001).

Colorimetry and TBARs were evaluated by regression as a function of time at $5 \%$ probability level (SAS, 2001).

For sensory analysis $(\mathrm{n}=50)$ generalized linear models (GENMOD procedure) were used, considering the distribution of variables as gamma with inverse link function, using the Statistical Analysis System program (SAS, 2001).

The composition analysis of the flours and the microbiological analyses were examined in order to only characterize the pâtés, but only descriptively.

\section{RESULTS AND DISCUSSION}

\section{Microbiological analysis of flours and pâtés}

Among the microbiological analyses were the quantification of the most probable number of total coliforms per gram, the most probable number of fecal coliforms per gram, Staphylococcus coagulase positive in colony forming units per gram and Salmonella spp (APHA, 1992). The microbiological protocol followed the standards recommended by Resolution RDC No. 12 of January 2, 2001, of the National Health Surveillance Agency (BRASIL, 2001). The results obtained are shown in Table 2.

The microbiological analysis of the flours and pâtés showed $<3 \mathrm{MPN}$ of coliforms at 35 and $45^{\circ} \mathrm{C}, 1 \times 102$ of Sthapylococcus coagulase positive and absence of Salmonella sp. (Table 3). This indicates that the flours and pâtés were within the microbiological standards required by the Brazilian legislation (BRASIL, 2001), whose values for Coliforms at $35^{\circ} \mathrm{C}$ and $45^{\circ} \mathrm{C}$ are lower than $3 \mathrm{MPN} / \mathrm{g}$, Staphylococcus coagulase positive less than $1 \times 102 \mathrm{CFU} \mathrm{g}^{-1}$, and absence of Salmonella

Table 2. Microbiological analysis of pâtés and flours from smoked fish carcasses

\begin{tabular}{|c|c|c|c|c|}
\hline \multirow[b]{2}{*}{ Treatment } & \multicolumn{4}{|c|}{ Microbiological analysis } \\
\hline & $\begin{array}{l}\text { Coliforms at } 35^{\circ} \mathrm{C} \\
\text { (MPN/g) }\end{array}$ & $\begin{array}{l}\text { Coliforms at } 45^{\circ} \mathrm{C} \\
\text { (MPN/g) }\end{array}$ & $\begin{array}{l}\text { S. coagulase positive } \\
\text { (CFU/g) }\end{array}$ & $\begin{array}{l}\text { Salmonello } \\
\text { sp. } 25 \mathrm{~g}\end{array}$ \\
\hline \multicolumn{5}{|l|}{ Flours } \\
\hline Salmon & $<3$ & $<3$ & $<10^{2}$ & Absence \\
\hline Tilapia & $<3$ & $<3$ & $<10^{2}$ & Absence \\
\hline \multicolumn{5}{|l|}{ Pâtés } \\
\hline Flourless & $<3$ & $<3$ & $<10^{2}$ & Absence \\
\hline Smoked Salmon & $<3$ & $<3$ & $<10^{2}$ & Absence \\
\hline Smoked Tilapia & $<3$ & $<3$ & $<10^{2}$ & Absence \\
\hline
\end{tabular}

MPN= Most Probable Number; $\mathrm{CFU}=$ Colony Forming Unit. 
in $25 \mathrm{~g}$ of sample, inferring that the flours and pâtés produced in this study were suitable for human consumption.

\section{Physicochemical analysis of the flours and pâtés}

\section{Centesimal composition of smoked salmon and tilapia carcass flours}

Table 3 shows the composition of the two flours prepared for inclusion in the pâté of tilapia trimmings. The moisture content of the salmon and tilapia flour found (Table 3) were below the classification of fish flours, because according to the Regulation of Industrial and Sanitary Inspection of products of animal origin (RIISPOA, 1997), the intact dried fish should not contain more than $12 \%$ of moisture.

The protein content was high for both smoked carcass flours, where salmon presented $52.66 \%$ and tilapia $65.52 \%$ (Table 3). When using the same smoking methodology to obtain flours, Coradini (2018) obtained a similar value for tilapia flour, (50.91\%), whereas for salmon flour the protein value of salmon flour was lower than that of the present study (45.86\%). These values differ from those obtained in this

Table 3. Centesimal composition and caloric value of smoked salmon and tilapia carcass flours

\begin{tabular}{l|c|c}
\multirow{2}{*}{ Nutrients (\%)* } & \multicolumn{2}{|c}{ Smoked carcass flour } \\
\cline { 2 - 3 } & Salmon & Tilapia \\
\hline Humidity & 6.11 & 8.10 \\
\hline Crude Protein & 52.66 & 65.52 \\
\hline Lipids & 13.76 & 9.89 \\
\hline Ash & 33.16 & 22.48 \\
\hline Caloric Value** $^{*}$ & 336.08 & 327.09 \\
\hline
\end{tabular}

* Carbohydrate Value lower than $1 \%$. * Caloric value refers to kcal. $100 \mathrm{~g}^{-1}$ work, probably due to the fact that the raw material used to obtain the flours is filleting waste and its meat content varies according to the methodology, operator, size, and fish species.

Souza et al. (2017) worked with several fish species during the preparation of carcass flours, using a methodology different from this experiment, and obtained for tilapia and salmon the contents of total lipids of 5.82 and $18.81 \%$, respectively. Coradini (2018), on the other hand, reported much higher lipid contents for the same fish species, using the same methodology.

The ash content of both salmon and tilapia carcass flours in Table 3 is considered high due to the presence of bones (spinal column and ribs) and the addition of salt in the process of salting the carcasses for smoking. Coradini (2018) presents a tilapia flour prepared by the same methodology with 28.57 $\%$ of ash, while that of salmon has $22.74 \%$. These differences for the various nutrients are due to the species and their intrinsic factors (chemical composition, feeding, raw material type used, or fish cut, among others) and the method used for preparing the flours.

\section{Centesimal composition of the pâtés}

The tilapia trim pâtés with added flour from smoked salmon and tilapia carcasses differed significantly for all variables analyzed (Table 4).

The pâté without added fishmeal had higher moisture content when compared to pâtés with added fishmeal. This occurred due to the fact that fish meal is hygroscopic, regardless of the species, not having the capacity to retain water, facilitating the evaporation or loss of water to the environment (ASSUNÇÃO; PENA, 2007). There was no significant difference in protein content between the pâtés, while the fat content was more expressive $(\mathrm{p}<0.05)$ in the pâté with salmon flour. However, the ash content was significantly higher in pâtés with either tilapia or

Table 4. Centesimal composition of pâtés made from trimmings and MSM of Nile tilapia, with inclusion of smoked salmon and tilapia carcass flours

\begin{tabular}{|c|c|c|c|c|c|}
\hline \multirow{2}{*}{ Nutrients (\%) } & \multicolumn{3}{|c|}{ Trimmings Pâtés and Tilapia MSM } & \multirow{2}{*}{ P Value } & \multirow{2}{*}{ CV \%** } \\
\hline & Flourless & Salmon Flour & Tilapia Flour & & \\
\hline Humidity & $63.62 \pm 0.13 a$ & $59.75 \pm 0.13 b$ & $60.35 \pm 0.80 b$ & $<0.01$ & 1.03 \\
\hline Protein & $15.30 \pm 0.20$ & $15.67 \pm 0.06$ & $16.62 \pm 0.02$ & 0.06 & 1.01 \\
\hline Lipids & $11.59 \pm 0.12 b$ & $12.62 \pm 0.07 a$ & $11.20 \pm 0.25 b$ & $<0.01$ & 1.89 \\
\hline Ashes & $9.49 \pm 0.12 b$ & $12.10 \pm 0.26 a$ & $12.42 \pm 0.54 a$ & $<0.01$ & 4.05 \\
\hline Carbohydrates & $2.12 \pm 0.03 a$ & $1.98 \pm 0.03 b$ & $1.65 \pm 0.02 c$ & $<0.01$ & 1.69 \\
\hline Caloric Value* & $173.96 \pm 1.55 b$ & $184.22 \pm 0.78 a$ & $173.92 \pm 2.40 \mathrm{~b}$ & $<0.01$ & 1.27 \\
\hline Salt & $1.66 \pm 0.11 b$ & $2.38 \pm 0.03 a$ & $2.32 \pm 0.14 a$ & $<0.01$ & 6.52 \\
\hline Collagen & $0.96 \pm 0.02 b$ & $1.42 \pm 0.02 a$ & $1.49 \pm 0.09 a$ & $<0.01$ & 5.38 \\
\hline $\mathrm{pH}$ & $6.00 \pm 0.03$ & $6.02 \pm 0.00$ & $5.97 \pm 0.02$ & 0.06 & 0.48 \\
\hline Aw & $0.832 \pm 0.00 a$ & $0.816 \pm 0.01 b$ & $0.816 \pm 0.00 b$ & 0.03 & 0.80 \\
\hline
\end{tabular}

Averages in the same row followed by different letters differed by Tukey's test $(\mathrm{p}<0.05)$. ${ }^{*}$ caloric value $\left(\mathrm{kcal} .100 \mathrm{~g}^{-1}\right)$. ${ }^{*} \mathrm{CV}$, coefficient of variation. Data expressed as mean \pm standard deviation. 
salmon flour. This result was expected, since the flours used in the preparation of the pâtés (Table 3) had a high content of mineral matter, as mentioned, which is due to the bones present in the carcass (bone with ribs and remaining meat) of the species used in this experiment, in addition to the salt from the brining $(10 \%)$ in the smoking process.

The collagen and salt contents were significantly lower in the pâté without the inclusion of flours (Table 4). As the flours were smoked, and this process includes the brining stage, which consists of immersing the carcasses in saturated salt solution, the salt content in these flours is relatively high. Thus, it is possible to observe higher salt values in the pâtés with the inclusion of the flours.

Regarding collagen content, there are no specifications on the allowable amounts of connective tissue or collagenous proteins in Brazil, as there are in the European Union (EU) regulations, which limits the amount of collagenous connective tissue allowed for the meat ingredient from mammalian animals (except for rabbits and pigs), which is $25 \%$, for pork meat which is also $25 \%$, and poultry and rabbits, $10 \%$ (CE, 2004), and the United States (USA) which limits the use of porcine collagen in sausages up to $3.5 \%$ (NARA, 2008). Thus, the values found in this study are in accordance with the American and European legislation (Table 4).

The amount of collagen in meat raw materials has a limiting content for its use (OLIVEIRA; OLIVEIRA, 2011). When in high amounts in the product mass, it causes changes in the final product, such as: gelatin accumulation, formation of gelatinous coating between the product and its wrapping, changes in yield, texture, emulsion stability, color, flavor, shelf life, and nutritional value (POUTTU; POULANNE, 2004).

The carbohydrate contents showed significant differences for all treatments (Table 4), ranging from 1.65\% for the pâté with tilapia flour inclusion and $2.12 \%$ for the treatment without added flour. These values are in accordance with the recommended by the legislation, whose values should vary between 1 and $10 \%$ (BRASIL, 2000). However, the lower carbohydrate content in the pâtés is due to the $300 \mathrm{~g}$ of fish flour that was included in the pâté.

The caloric value was more expressive $(\mathrm{p}<0.05)$ for the pâté with salmon flour inclusion (Table 4), resulting from the higher fat content present in the flour (Table 3). According to Minozzo (2016), the caloric value of fish, as food, particularly depends on the fat content.

All three pâté formulations were within the humidity, fat, and protein standards established by Brazilian legislation. According to the regulation, pâtés can have a maximum of $70 \%$ humidity and $32 \%$ fat, while the minimum protein content is $8 \%$ (BRASIL, 2000).

Minozzo, Waszczynkyj, and Beirão (2008) obtained similar values for moisture (59.47\%) and carbohydrate (2.39\%) in the tilapia pâté when working with tilapia pâté and commercial brands, tuna, and ham pâté; However, for the lipid content of ham pâté (17.72\%), it was much higher than in the present study with trimmed pâté and MSM, regardless of the inclusion of smoked salmon and tilapia carcass flours. The ash and protein contents were relatively lower than in the present study. The average values of ash were $2.20 \%$ for tilapia pâté, $2.96 \%$ for tuna pâté, and $2.53 \%$ for ham pâté, while protein was $8.53,6.83$, and $9.05 \%$ for tilapia, tuna, and ham pâté, respectively.

When working with the production of armado (Pterodoras granulosus) pâté and its microbiological, sensory, and physicochemical characterization, Minozzo; Waszczynkyj; Boscolo (2010) obtained average values for the composition of pâté of $61.5 \%$ of moisture, $10 \%$ of protein, $25 \%$ of lipids, $2.5 \%$ of ash, and $1.4 \%$ of carbohydrates, similar to this study in the composition of moisture, protein, and carbohydrates (Table 4). Nevertheless, the ash values are much lower since the aforementioned authors did not use bone parts in the elaboration of the pâtés. The lipid content of $25 \%$ obtained by Minozzo; Waszczynkyj; Boscolo (2010) is higher than the results obtained in the present study. The fat content of the pâté is very important for the formation of the emulsion characteristic of this product.

According to Schiffner; Oppel; Lörtzing (1996), for a pâté to comprise an optimal amount of fat, it should average between 20 and $60 \%$. Too low or too high values influence the final quality of the product. A pâté with less than $20 \%$ fat loses its mellifluousness, becoming dry and repulsive when filled, and when it dries out, a gray outer layer forms. The fat used can be soft or hard, and fresh, as it determines the flavor of the final product. However, other authors have also reported low lipid values, such as Echarte et al. (2003), who, when studying the nutritional evaluation of salmon, anchovy, and codfish pâtés, reported values of 16.10 and $13.72 \%$ for anchovy and codfish pâtés, respectively. Likewise, Aquerreta et al. (2002) and Minozzo; Waszczynkyj; Beirão (2008) mentioned values of $10.01 \%$ and $3.69 \%$ of lipids in tuna pâtés, respectively. Nonetheless, when making pâtés, a minimum fat content of $20 \%$ must be considered in order to maintain the characteristic pattern of the product.

The $\mathrm{pH}$ did not present any difference $(\mathrm{p}>0.05)$ among treatments (Table 4); however, the $\mathrm{pH}$ averages (5.97 to 6.02) agree with the expected values for this type of product, according to Estévez et al. (2005). According to these results, the pâtés can be classified as low acid ( $\mathrm{pH}>4.5$ ), pursuant to the Sanitary Standards of the Adolfo Lutz Institute (IAL, 1967). These $\mathrm{pH}$ values are compatible with other fish products, such as: shrimp (6.8 to 7.0), fresh fish (6.6 to 6.8), and crustaceans (6.8 to 7.0) (IANFES, 1997); tilapia pâté (6.65 to 6.68) (MINOZZO, 2010); and ham pâté (6.57) (SILVA et al., 2003).

The Aw of the pâtés maintained average values close to 0.824, which was the highest value for the pâté without flour inclusion (Table 4), indicating that the inclusion of the flours tends to decrease the Aw; however, both pâtés presented high 
values for this variable, and these values were above the borderline zone ( $>0.60$ ) for the development of microorganisms. However, the Aw values presented in this study were lower than those reported by Minozzo; Waszczynkyj; Boscolo (2010) for pâtés with the creamy type armado fish $(\mathrm{Aw}=0.943)$. Microbiological quality, humidity, $\mathrm{Aw}$, and $\mathrm{pH}$ are relevant factors in maintaining food quality. The high $\mathrm{pH}$ associated with high water activity can favor the proliferation of microorganisms, such as Salmonella, Campylobacter, Yersinia, E. Coli, Shiguella, Clostridium, S. Aureus (IANFES, 1997).

\section{Colorimetry analysis of the pâtés}

The brightness intensity of the pâtés did not vary throughout the 30-day shelf-life period $(\mathrm{P}<0.05)$, (Table 5). Nevertheless, at the beginning of shelf-life, at time zero, the pâtés showed significantly higher luminosity for the PSF, while the PFSD did not differ $(\mathrm{P}<0.05)$ from the others. The luminosity varied from 60.6 to 46.04 , representing a reduction of $25 \%$, depending on the inclusion of smoked fish flour and the species of fish used for the flour. Thus, the PSF treatment (without the inclusion of flour) obtained the highest average for the $\mathrm{L}^{*}$ coordinate, while the PFTD treatment, with inclusion of smoked tilapia flour, presented the lowest average, indicating darker pâtés, that is, the inclusion of the flours decreased the brightness of the pâtés.

There was no significant difference for the red tendency (coordinate $\mathrm{a}^{*}$ ) among the treatments throughout the 30 days of shelf life, whose average value was around 6.4. Regarding the evaluated times, this variable differed among treatments only at time zero. This is due to the inclusion of smoked salmon and tilapia carcass flours in the pâtés (PFSD $=7.27$, and PFTD $=$ 6.21), compared to those that did not include the flours (PSF $=5.24)$. However, when salmon flour was added, the red tendency was significantly higher than when smoked fish flour was not included (PSF), (Table 6). This result is justified due

Table 5. Colorimetric analysis of fish chip pâtés with added smoked salmon and tilapia carcass flours over 30 days

\begin{tabular}{|c|c|c|c|c|c|c|}
\hline \multirow{2}{*}{ Variable } & \multirow{2}{*}{ Time } & \multicolumn{3}{|c|}{ Treatment } & \multirow{2}{*}{ P Value } & \multirow{2}{*}{ C.V. (\%) } \\
\hline & & PSF & PFSD & PFTD & & \\
\hline \multirow{3}{*}{ Luminosity } & 0 & $62.17 \pm 1.25 a$ & $58.11+0.21 a b$ & $44.76 \pm 1.60 \mathrm{~b}$ & 0.012 & \multirow{3}{*}{14.72} \\
\hline & 15 dias & $60.56 \pm 0.39$ & $54.33 \pm 0.62$ & $47.14 \pm 1.89$ & 0.149 & \\
\hline & 30 dias & $59.26 \pm 470$ & $56.52 \pm 3.70$ & $46.23 \pm 1.60$ & 0.138 & \\
\hline PValue & & 0.906 & 0.846 & 0.935 & & \\
\hline \multirow{3}{*}{ Chromaticity $a^{*}$} & 0 & $5.24 \pm 0.04 b$ & $7.27 \pm 0.10 a$ & $6.21+0.25 a b$ & 0.012 & \multirow{3}{*}{11.63} \\
\hline & 15 dias & $6.23 \pm 0.14$ & $7.10 \pm 0.32$ & $6.51+0.22$ & 0.367 & \\
\hline & 30 dias & $5.43 \pm 0.17$ & $6.75 \pm 0.18$ & $6.57 \pm 0.26$ & 0.862 & \\
\hline PValue & & 0.243 & 0.692 & 0.816 & & \\
\hline \multirow{3}{*}{ Chromaticity b* } & 0 & $14.06 \pm 0.58 \mathrm{~B}$ & $13.68 \pm 0.10 \mathrm{~B}$ & $13.92 \pm 0.06$ & 1.00 & \multirow{3}{*}{12.32} \\
\hline & 15 dias & $18.74 \pm 0.12 \mathrm{Aa}$ & $17.62 \pm 0.39 A a \mathrm{Aab}$ & $14.84 \pm 0.05 b$ & 0.045 & \\
\hline & 30 dias & $13.32 \pm 0.23 B$ & $12.55 \pm 0.18 \mathrm{~B}$ & $14.09 \pm 0.05$ & 0.60 & \\
\hline PValue & & $<0.01$ & $<0.01$ & 0.805 & & \\
\hline
\end{tabular}

Averages in the same row followed by distinct lowercase letters differ among themselves by the Tukey test $(p<0.05)$. Averages in the same column followed by different capital letters differ by the Tukey test $(p<0.05)$. CV, coefficient of variation. Data expressed as mean \pm standard deviation. PSF, pâté without flour inclusion. PFSD, pâté with smoked salmon flour inclusion. PFTD, pâté with smoked tilapia flour inclusion.

Table 6. Sensory analysis of fish trimmings pâtés with added smoked salmon and tilapia carcass flours

\begin{tabular}{|c|c|c|c|c|c|}
\hline \multirow{2}{*}{ Variables } & \multicolumn{3}{|c|}{ Treatments } & \multirow{2}{*}{ P Value* } & \multirow{2}{*}{ C.V } \\
\hline & PSF & PFSD & PFTD & & \\
\hline Color & $6.76 \pm 1.22 \mathrm{a}$ & $5.76 \pm 1.74 \mathrm{~b}$ & $6.20 \pm 1.58 a b$ & 0.0333 & 30.44 \\
\hline Aroma & $6.90 \pm 1.20$ & $6.14 \pm 1.66$ & $6.16 \pm 1.56$ & 0.0672 & 28.85 \\
\hline Texture & $6.72 \pm 1.23$ & $5.94 \pm 1.63$ & $6.08 \pm 1.56$ & 0.0768 & 29.13 \\
\hline Flavor & $6.80 \pm 1.48$ & $6.44 \pm 1.59$ & $6.00 \pm 1.96$ & 0.1666 & 32.80 \\
\hline Overall impression & $6.86 \pm 1.45 a$ & $5.80 \pm 1.72 b$ & $5.88 \pm 1.84 \mathrm{~b}$ & 0.0179 & 33.21 \\
\hline Purchase Intention & $3.50 \pm 0.78$ & $3.00 \pm 0.96$ & $3.08 \pm 0.98$ & 0.0667 & 35.81 \\
\hline
\end{tabular}

* Averages in the same row followed by distinct letters differed by the Tukey test $(p<0.05)$. CV, coefficient of variation. Data expressed as mean \pm standard deviation. PSF, pâté without flour inclusion. PFSD, pâté with smoked salmon flour inclusion. PFTD, pâté with smoked tilapia flour inclusion. 
to the greater intensity in the salmon meat color, associated with the smoking process that provides a redder color to the product. According to Canhos; Dias (1900), in the smoking process, the smoke compounds react with amino acids in the product, occurring the well-known Maillard reaction, determining a redder shade to the product.

During the 30 days of shelf-life evaluation of the pâtés, there was a significant change for the $b^{*}$ coordinate in the PSF and PFSD pâtés (Table 5). There was an increase in the $b^{*}$ coordinate on the $15^{\text {th }}$ day, and then it decreased again with values similar to time zero. The PFTD, however, did not vary throughout the 30-day storage period, but at 15 days (14.84) the value was significantly lower than the PSF and PFSD, 18.74 and 17.62, respectively, showing that the PFTD had less brightness (Table 5) in the 30 days cycle and, consequently, less variation in the tendency to yellow color. This may be associated with oxidation reactions that can occur during storage, changing the color of the product.

The values obtained in the present work for the variables of Luminosity (62.21), coordinates a* (5.24) and b* (14.06), differ from the results obtained by Minozzo (2010) for tilapia pâté, whose values were 69.0, 7.18, and 12.97, respectively, which may be associated with the contents of MSM used in both works.

\section{Determination of lipid oxidation by thiobarbituric acid (TBARs)}

According to the shelf-life of the PSF, PFSD, and PFTD, it was possible to observe changes in malonaldehyde (MDA) levels over the 90 days $(\mathrm{p}<0.05)$, for all treatments (Figure 1). These changes were evaluated by regression analysis.

Initially, the MDA. $\mathrm{kg}^{-1}$ values of the samples were 2.82, 2.96, and 3.01 for the PFSD, PSF, and PFTD, respectively. PSF had its peak MDA production at 15 days shelf-life, achieving values of $6.52 \mathrm{mg}$ of MDA. $\mathrm{kg}^{-1}$, reaching $4.52 \mathrm{mg}$ at 90 days $\left(y=3.324+0.301 x-0.039 x^{2}, R^{2}=0.78\right)$.

The oxidation peak for PFSD (6.04mg of MDA. $\left.\mathrm{kg}^{-1}\right)$ and PFTD (6.52mg of MDA. kg ${ }^{-1}$ ) occurred around the 45 days of shelf-life, reaching the value of 5.0 and $5.45 \mathrm{mg}$ of MDA. $\mathrm{kg}^{-1}$, respectively. Thus, the equation presented for each of the prepared pâtés was quadratic $\left(\mathrm{y}=1.1399+1.7253 \mathrm{x}-0.1683 \mathrm{x}^{2}\right.$, $\mathrm{R}^{2}=0.89$ and $\left.\mathrm{y}=0.9766+2.1215 \mathrm{x}-0.2146 \mathrm{x}^{2}, \mathrm{R}^{2}=0.95\right)$, respectively for PFSD and PFTD.

The pâtés with inclusion of smoked fish carcass flours took longer to reach the peak of oxidation, and for PFSD and PFTD it took about 45 days, while the pâté that did not have smoked fish flour included reached the peak with only 15 days of storage. This shows that the pâtés with fishmeal provided a longer shelf life for them. This occurred due to antioxidant traces from the carcass flour (BHT).

The results obtained in this study are similar to Pateiro et al. (2014) who worked with pork pâté and obtained initial values of $2.9 \mathrm{mg}$ of MDA. $\mathrm{kg}^{-1}$, reaching an oxidation peak of $4.3 \mathrm{mg}$ of MDA. $\mathrm{kg}^{-1}$; however, in this study the time was much shorter (approximately five days of storage) than the time used in this experiment of pâtés with fish trimmings.

The TBARs levels indicate the high presence of malonaldehyde during the evaluation period, since the TBARs values obtained were higher than 0.16 mg of MDA. $\mathrm{kg}^{-1}$, which,

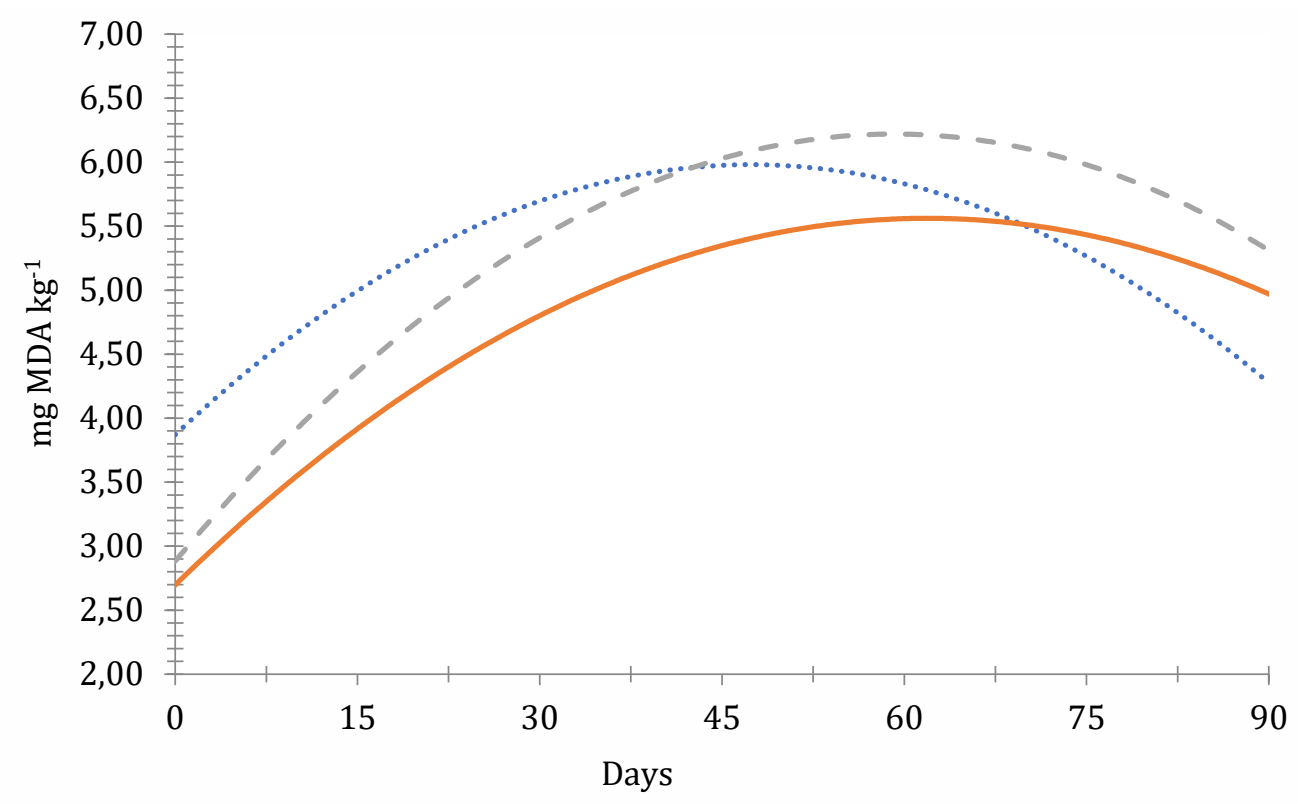

Polinomial (PSF) $\longrightarrow$ Polinomial (PFSD) --- Polinomial (PFTD)

Figure 1. Evolution of thiobarbituric acid reactive substances (TBARs) during the 90-day shelf-life of pâtés without fishmeal inclusion (PSF), with smoked salmon flour inclusion (PFSD) and with tilapia flour inclusion (PFTD). 
according to Terra; Cichoski; De Freitas (2006), can be harmful to the consumer's health. The control of oxidative reactions is an extremely important factor for health, since several authors indicate that high values of TBARs, which are substances arising from rancidification, are toxic, carcinogenic, and mutagenic. In Brazil, no legislation limits the amount of malonaldehyde/kg in meat products; however, some authors consider that values lower than $3 \mathrm{mg}$ of MDA. $\mathrm{kg}^{-1}$ of sample are considered satisfactory for the quality of products (AL-KAHTANI et al., 1996). Therefore, according to this information, the PFSD and PFTD treatments reached levels higher than $3 \mathrm{mg} \mathrm{MDA.} \mathrm{kg}^{-1}$ near the 15-day shelf-file, indicating that they were unfit for consumption and that preventive measures for oxidation should be taken so that this type of product remains stable.

\section{Sensory analysis of the pâtés}

No difference $(\mathrm{p}>0.05)$ was found among the sensory attributes, aroma, texture, and flavor. These attributes received average scores of 6.35, which, according to Dutcosky (2011), corresponds to slightly liked to moderately liked. The mean scores assigned by the evaluators for pâté coloration and overall impression indicated a preference for PSF. However, regardless of the treatment, purchase intention was low ( $p>0.05)$, indicating that the testers "might/might not buy" (Table 6). The results of the sensory analysis, particularly the purchase intention, may indicate that the tested public has an animosity towards fish products or even pâtés.

The sensory attributes obtained in this study showed averages higher than those reported by Minozzo; Waszczynkyj; Boscolo (2010), where, when evaluating pâté made from armado fish (Pterodoras granulosus), they did not obtain averages higher than 4.00. Bordignon et al. (2006) also found acceptable and quality standards for creamy pâtés of tilapia and pacu, whose values were similar to those of the attribute test performed for the pâtés in this study.
Through the averages of the variables present in the sensory analysis, the Acceptance Index (AI) of the pâtés made with tilapia fillet trimmings could be obtained, according to the number of tasters participating in the evaluation of this product. For the PSF treatment it was noted that the acceptance index was $84 \%$, compared to PFSD and PFTD, which reached $67.5 \%$, indicating that the inclusion of smoked carcass flours tends to decrease the acceptance index. As the product acceptance index, which according to Castro et al. (2007), should be equal to or greater than $70 \%$ to be considered accepted, these pâtés need some changes in the formulation to improve all the attributes evaluated, as well as to improve mainly the color of the pâtés, because in this particular situation, the PFSD presented the worst score (5.76), which may have contributed to a low acceptance rate.

Further studies are needed in this area to improve the methodology for preparing pâtés with filleting residues. This is mainly regarding sensory analysis, due to the ingredients to be added to enhance the color and provide a better impression to the consumer, as well as prolonging the time for the oxidation peak of these pâtés because of the changes that occur in the instrumental color.

\section{CONCLUSIONS}

The pâtés and flours were within microbiological standards for human consumption. The inclusion of the flours reduced the water activity and the moisture and carbohydrate content of the pâtés. The ash, salt, and collagen contents increased with the inclusion of the flours. The lipid content was higher in the pâte with the inclusion of smoked salmon carcass flour, and the protein content did not differ between the treatments. The inclusion of the flours influenced the colorimetry of the pâtés. The hedonic scale used in sensory analysis and purchase intention indicated good acceptance by consumers, but only the pâté without inclusion of flours reached a satisfactory value for the acceptance index.

\section{REFERENCES}

AL-KAHTANI, H. A. et al. Chemical Changes After Irradiation and Post-Irradiation Storage in Tilapia and Spanish Mackerel. Journal of Food Science, v. 61, n. 4, p. 729-733, 1996.

AOAC. Oficial Methods of Analysis of the Association of Official Analytical Chemists. Arlington. v. 2, cap. 35, p. 1-30, 1997.

APHA. Americam Pubblic Health Association. compendium of methods for the microbiological examination of foods. 3. ed. Washington, 1992.

AQUERRETA, Y. et al. Composition of pâtés elaborated with mackerel flesh(Scomberscombrus) and tuna liver(Thunnus thynnus): comparison with commercial fish pâtés. Food Chemistry. v. 77, p. 147-153, 2002.
ASSUNÇÃO, A. B.; PENA, R. S. Hygroscopic behavior of the dry residue of pink shrimp. Food Science and Technology. v. 27, $n$. 4, p. 786-793. 2007.

BLIGH, E. G.; DYER, W. J. A rapid method of total lipid extraction and purification. Canadian journal of biochemistry and physiology. v. 37. p. 911-17. 1959.

BORDIGNON, A. C. et al. Avaliação microbiológica e sensorial de patê cremoso de filé de tilápia (Oreochromis niloticus) e pacu (Piaractus mesopotamicus) defumados. In: CONGRESSO DA SOCIEDADE BRASILEIRA DE AQUICULTURA E BIOLOGIA AQUÁTICA, 4., 2006, Bento Gonçalves. Anais. Bento Gonçalves: Aquaciência, 2006. 
BORDIGNON, A. C. et al. Elaboração de croquete de tilápia do Nilo (Oreochromis niloticus) a partir de CMS e aparas do corte em ' $V$ 'do filé e sua avaliação físico-química, microbiológica e sensorial. Acta Scientiarum. Animal Sciences, v. 32, n. 1, p. 109-116, 2010.

BRASIL. Agência Nacional de Vigilância Sanitária. Resolução RDC nº 12 de 02de janeiro de 2001. Padrão Microbiológico para Alimentos. Brasília: Diário Oficial da União, 2001.

BRASIL. Manual oficial de contagem de carboidratos. Rio de Janeiro: Sociedade Brasileira de Diabetes, 2003

BRASIL. Ministério da Agricultura. Instrução Normativa no 21, de 31 de julho de 2000. Regulamento técnico para fixação dos padrões de identidade e qualidade para patês. Brasília: Diário Oficial [da] República Federativa do Brasil, 2000.

CANHOS, D. A. L.; DIAS E. L. Defumação. Tecnologia de Carne Bovina e Produtos Derivados. Secretaria da Ind., Com. Ciência e Tecnologia, 1900.

CASTRO, L. I. et al. Quinoa (Chenopodium quinoa Willd.): digestibilidade in vitro, desenvolvimento e análise sensorial de preparações destinadas a pacientes celíacos. Revista Alimentos e Nutrição, v. 18, n. 4, p. 413-419, 2007.

CE. Comunidade Europeia. Parlamento Europeu e do Conselho. Regulamento(CE) $n^{0} \mathbf{8 5 3} / \mathbf{2 0 0 4}$ de 29 de abril de 2004. Estabelece regras específicas de higiene aos gêneros alimentícios de origem animal. Bruxelas: Jornal Oficial das Comunidades Europeias, 2004.

CORADINI, M. F. Farinhas de tilápia do Nilo e salmão elaboradas por diferentes metodologias e sua aplicação em produto alimentício. 2018. 79 f. Dissertação (Mestrado em Zootecnia:) - Universidade Estadual de Maringá, Maringá, 2018.

DAMÁSIO, M. H.; SILVA, M. A. A. P. Curso de treinamento em análise sensorial. Campinas: Fundação Tropical de Tecnologia “André Tosello", 1996.

DO AMARAL M. T. et al. Sistema Cielab Para Avaliação Da Cor De Produtos Cárneos. Anais do Salão Internacional de Ensino, Pesquisa e Extensão, v. 4, n. 1, 2012.

DUTCOSKY S. D. Análise sensorial de alimentos. 3. ed. Curitiba: Champagnat, 2011.

ECHARTE, M. et al. Evaluation of the nutritional aspects and cholesterol oxidation products of pork liver and fish pâtés. Food Chemistry. v. 86, n. 1, p. 47-53, 2004.

ESTÉVEZ, M. et al. Characterisation of a traditional Finnish liver sausage and different types of Spanish liver pâtés: A comparative study. Meat Science, v.71, n. 4, p. 657-669, 2005.

Feiden, $A$. et al. Patê à base de pescado e sua caracterização físico-químico e sensorial. In: CONGRESSO BRASILEIRO DE PRODUÇÃO DE PEIXES NATIVOS DE ÁCUADOCE. Disponível em: <http:/www.cpao.embrapa.br/congressopeixe2007/TRABALHOS/ TECNOLOCIA_E_PROCESSAMENTO_DO_PESCADO/TECPESC_04. pdf $>$. Acesso em: 15 de jan. de 2019.

IAL. Instituto Adolfo Lutz. Normas analíticas do Instituto Adolfo Lutz: métodos químicos para análises de alimentos. 3. ed. São Paulo, 1985

IAL. Instituto Adolfo Lutz. Normas de qualidade de alimentos São Paulo: Ofsanpan, 1967.
IANFES. International Association of Milk, Food, and environmental Sanitarians. Guia de procedimento para Implantação do Método de Análise de perigos em Pontos críticos de Controle (APPCC). São Paulo, 1997.

JUNCHER, D. et al. Effect of pre-slaughter physiological conditions on the oxidative stability of colour and lipid during chill storage of pork. Meat Science, v. 58, n. 4, p. 347-57, 2001.

KUBITZA, F. Aproveitamento dos subprodutos do processamento de pescados. Panorama da Aquicultura, v. 16, п. 94, p. 23-29, 2006.

MATIUCCI, M. A. et al. Patês elaborados a partir de resíduos do beneficiamento de tilápia com e sem defumação. Iniciação Científica CESUMAR, v. 2l, n. 2, p. 163-173, 2019.

MEILGAARD, M.; CIVILE, G. V.; CARR, B. T. Sensory evaluation techniques. 2. ed. Boca Raton: CRC Press, 1991.

MINOZZO, M. G.;WASZCZYNSKYJ, N.; BEIRÃO, L. H. Características físico-químicas do patê de tilápia do Nilo (Oreochromis Niloticus) comparado a produtos similares comerciais. Alimentos \& Nutrição, v. 15, n. 2, p. 101-105, 2008.

MINOZZO, M. G.; WASZCZYNSKYJ, N.; BOSCOLO, W. R. Obtenção de patê de armado (Pterodoras granulosus) e a sua caracterização microbiológica, sensorial e físico-química. Brazilian Journal Food Technology, v. 13, n. 3, p. 182-188, 2010.

MINOZZO, M. G.; WASZCZYNSKYJ, N.; BOSCOLO, W. R. Utilização de carne mecanicamente separada de tilápia (Oreochromis niloticus) para a produção de patês cremoso e pastoso. Alimentos \& Nutrição, v. 19, п. 3, p. 315-319, 2008.

MINOZZO, M. G. Patê de pescado: alternativa para incremento da produção nas indústrias pesqueiras. 2010. 210 f. Tese (Doutorado em Tecnologia de Alimentos) - Universidade Federal do Paraná, Curitiba, 2010.

MINOZZO, M. G. Processamento e Conservação do Pescado. Curitiba: e-Tec Brasil, Instituto Federal do Paraná, 2016.

MORAES, M. A. C. Métodos para avaliação sensorial dos alimentos. 8. ed. Campinas: UNICAMP. 1993.

NARA. National Archives and Records Administration. Department of Agriculture. Code of Federal Regulations - Title 9 - Animals and Animal Products - Chapter III - Food Safety and Inspection Service, revised as of January 1, 2008. 9 CFR Cha III, Part 319 Definitions and Standards of Identity or Composition. Disponível em: <http:/www.access.gpo.gov/nara/cfr/waisidx08/9cfr319_08. html>. Acesso em: 19 dez. 2019.

OLIVEIRA, A. L.; OLIVEIRA, R. B. P.; Determinação do teor de hidroxiprolina em diversas classes de embutidos e em carnes industriais. Revista de Educação Continuada em Medicina Veterinária e Zootecnia do CRMV-SP, v. 9, n. 3, p. 74-74, 2011.

PATEIRO, M. et al. Effect of addition of green tea, chestnut, and grape extract on the shelf-life of pig liver pâté. Food chemistry, v. 147, p. 386-394, 2014.

POUTTU, P.; PUOLANNE, E. A procedure to determine the water-binding capacity of meat trimmings for cooked sausage formulation. Meat science, v. 66, n. 2, p. 329-334, 2004 
RIISPOA. Regulamento da Inspeção Industrial e Sanitária de Produtos de Origem animal. Ministério da Agricultura, Pecuária e Abastecimento. Seção II - Derivado do Pescado, Artigo 466. Brasília, 1997.

SAS - Statistical Analysis System - SAS. SAS/STAT user's guide. The GENMOD procedure. 2001.

SCHIFFNER, E.; OPPEL, K.; LÖRTZING, D. Elaboración casera de carne y embutidos. Zaragoza: Acribia, 1996.

SILVA, D. J.; QUEIROZ, A. C. Análise de Alimentos: Métodos Químicos e Biológicos. Viçosa: Universidade Federal De Viçosa, 2002.

SILVA, F. V. et al. Características morfométricas, rendimentos de carcaça, filé, vísceras e resíduos em tilápias-do-nilo em diferentes faixas de peso. Revista Brasileira de Zootecnia, v. 38, n. 8, p. 1407-1412, 2009.
SILVA, J. G. et al. Avaliação da estabilidade e da qualidade do patê de presunto, adicionado de globina bovina e de caseinato de sódio, como agente emulsionante. Ciência e Tecnologia de Alimentos, v. 23, n. 1, p. 10-15, 2003.

SOUCI, S. W.; FACHMAN, H.; KRAUT, E. Foods Composition and Nutrition Tables. 6. ed. Medpharm, 2000.

SOUZA, M. L. R. et al. Formulation of fish waste meal for human nutrition. Acta Scientiarum Technology, v. 39, p. 525-531, 2017.

STONE, H.; SIDEL, J. L. Sensory Evaluation Practices. 2. ed. San Diego: Academic Press, 1993.

TERRA, N. N.; CICHOSKI, A. J.; DE FREITAS, R. J. S. Valores de nitrito e TBARs durante o processamento e armazenamento da paleta suína curada, maturada e fermentada. Ciência Rural, v. 36, п. 3, p. 965-970, 2006. 